Vol. 7 No. 1, April 2021 (28-39)

JURNAL KEOLAHRAGAAN

https://jurnal.unigal.ac.id/index.php/JKP

\title{
Pengaruh Program Fundamental Movement Skills Terhadap Pengembangan Proses Sosial (Assosiatif dan Disosiatif) Siswa SD
}

\author{
Ucu Abdul Ropi dan Gani Kardani \\ Program Studi Pendidikan Jasmani, Universitas Galuh, Ciamis, Indonesia \\ Email: Ucuabdul@gmail.com
}

\begin{abstract}
This research was motivated by the issue of children who tend to choose passive play activities and did not master basic movements as a provision for socializing. Through the FMS program, children were introduced to basic movements (locomotor, non-locomotor and manipulative). Good mastery of basic movements (FMS), children were able to interact and socialize with the surrounding environment. Method (True Experiment). Design (Randomized posttest only control group designs). The population was all students of SDN 4 Sindangrasa, a sample of 64 students 32 group A and 32 group B. The results showed a thit value of 3.658 with probability (p) Sig. $0.001<0.05$, so Ho is rejected, meaning that "there was an influence of the FMS program on the development of the social (associative) process of elementary students". It was known that the tit value was 1.010 with probability (p) Sig. 0.275> 0.05 then Ho was accepted, meaning that "there was no influence of the FMS program on the development of the social (dissociative) process of elementary students". The FMS program was able to have a significant influence on the development of the social process (associative) of elementary students. The FMS program does not have a significant influence on the development of the social (dissociative) process of elementary students.
\end{abstract}

Keywords: Elementry student, FMS, Social procees

\begin{abstract}
ABSTRAK
Penelitian ini dilatar belakangi oleh isu anak yang cenderung memilih aktifitas permainan yang pasif dan kurang menguasai gerak dasar sebagai bekal untuk bersosialisasi. Melalui program $F M S$ anak diperkenalkan gerak dasar (lokomotor, non-lokomotor dan manipulatif). Penguasaan gerak dasar (FMS) yang baik, anak mampu berinteraksi dan bersosialisasi dengan lingkungan sekitar. Metode (True Eksperimen). Desain (Randomized posttest only control group designs). Populasi adalah seluruh siswa SDN 4 Sindangrasa, sampel 64 orang siswa 32 orang kelompok A dan 32 orang kelompok B. Hasil penelitian menunjukan nilai thit 3,658 dengan probabilitas (p) Sig. 0,001<0,05 maka $\mathrm{H}_{\mathrm{o}}$ ditolak, artinya bahwa "Terdapat pengaruh program FMS terhadap pengembangan proses sosial (asosiatif) siswa SD”. Diketahui nilai thit 1,010 dengan probabilitas (p) Sig. 0,275>0,05 maka $\mathrm{H}_{\mathrm{o}}$ diterima, artinya bahwa "Tidak terdapat pengaruh program FMS terhadap pengembangan proses sosial (disosiatif) Siswa SD”. Program FMS mampu memberikan pengaruh yang signifikan terhadap pengembangan proses sosial (Asosiatif) siswa SD. Program FMS tidak memberikan pengaruh yang signifikan terhadap pengembangan proses sosial (disosiatif) siswa SD.
\end{abstract}

Kata Kunci: Proses Sosial, FMS, Siswa SD

Cara sitasi:

Ropi. U.A. \& Kardani. G (2021). Pengaruh Program Fundamental Movement Skills Terhadap Pengembangan Proses Sosial (Assosiatif dan Disosiatif) Siswa SD. Jurnal Keolahragaan Pendidikan Jasmani. Unigal, 7(1), 28-39. 


\section{PENDAHULUAN}

Dalam menjalankan kehidupan sehari-hari setiap manusia tidak dapat hidup sendiri untuk mencukupi kebutuhan hidup. Manusia sebagai makhluk sosial artinya manusia sebagai warga masyarakat yang hidup berdampingan dengan manusia lainnya yang berbeda suku, bahasa, dan agama. Meskipun manusia mempunyai kedudukan dan jabatan yang tinggi, manusia selalu membutuhkan manusia lain dalam melakukan suatu hal yang tidak dapat dilakukannya. Setiap manusia cenderung untuk berkomunikasi, berinteraksi, dan bersosialisasi dengan manusia lain. Dalam sosialisasi inilah manusia selalu mengadakan penyesuaian dalam lingkungan sekitarnya, namun tidak sedikit dari mereka yang mengalami kesulitan dalam melakukan penyesuaian. Dalam konteks pembelajaran pendidikan jasmani, interaksi terjadi antara guru dengan siswa, siswa laki-laki dengan siswa laki-laki, siswa laki-laki dengan siswa perempuan dan sebaliknya. Interaksi tersebut bisa saling mempengaruhi, pengaruh tersebut bisa berupa pengaruh yang bersifat positif, bisa juga pengaruh yang bersifat negatif. Proses saling mempengaruhi bisa terjadi dalam aspek kognitif, apektif, dan psikomotor. Pada tingkatan Sekolah Dasar faktor guru, teman sebaya, dan lingkungan sekolah memberikan pengaruh yang lebih besar dibandingkan dengan pengaruh orang tua atau pihak lain yang berada di lingkungan masyarakat. Sebagai contoh adalah ketika seorang guru memberikan intruksi organisasi untuk membuat kelompok kepada siswa, dengan segera siswa membentuk suatu kelompok, kegiatan tersebut secara tidak langsung telah terjadi sebuah interaksi antar siswa dalam kelompok tersebut. Kegiatan siswa yang dilakukan dalam proses pembelajaran penjas mencerminkan kehidupan sosial yang nyata meskipun dalam ruang lingkup yang lebih kecil yaitu di lingkungan sekolah. Sesungguhnya dari proses pembelajaran yang dilakukan di sekolah siswa mulai berinteraksi dengan individu-individu yang lain, yang berbeda latar belakang sosial, keluarga, lingkungan, bahkan berbeda agama. Sekolah sebagai lembaga formal memberikan kaidah-kaidah dan norma-norma yang baik yang berlaku di lingkungan masyarakat yang dikemudian hari bisa diimplementasikan oleh siswa pada lingkungan masyarakat yang sebenarnya.

Interaksi sosial merupakan syarat utama terjadinya aktivitas-aktivitas sosial (Soekanto, 2012, hlm. 55). Berlangsungnya suatu proses interaksi didasarkan pada berbagai faktor, antara lain faktor imitasi, sugesti, identifikasi dan simpati. Imitasi terkait dengan proses meniru atau mencontoh suatu prilaku yang dianggap baik dan disukai secara umum. Sugesti berhubungan dengan proses penerimaan suatu pandangan sampai menjadi suatu keyakinan, identifikasi merupakan kecenderungan atau keinginan dalam diri seseorang untuk menjadi sama dengan pihak lain. Keterkaitan dalam pembelajaran penjas dari keempat faktor tersebut terjadi dalam setiap sesi pembelajaran penjas. Sebagai contoh pada faktor imitasi, seorang siswa akan meniru apa yang dilakukan atau didemonstrasikan oleh guru, baik itu dalam konteks mendemonstrasikan sebuah materi dalam pembelajaran penjas maupun dalam luar pembelajaran penjas, yaitu dalam sikap yang dilakukan oleh guru secara langsung dapat juga mempengaruhi sikap siswa. Pada faktor sugesti terjadi ketika seorang anak memakai aksesoris ketika bermain sepak bola, dengan memakai aksesoris tersebut anak memiliki suatu keyakinan/sugesti yang tinggi dalam dirinya bahwa dengan memakai aksesoris penampilannya akan menjadi lebih baik. Faktor identifikasi dalam proses pembelajaran penjas adalah ketika seorang siswa dapat melakukan suatu gerakan dengan baik dan benar dan mendapat pujian dari guru, siswa yang lain cenderung untuk meniru supaya gerakannya sama dengan siswa tersebut. Faktor simpati dalam konteks pembelajaran penjas adalah terjadi ketika salah seorang siswa memiliki kemampuan di atas rata-rata siswa lain, secara tidak langsung siswa memiliki daya tarik terhadap siswa lain untuk lebih dekat dengan siswa tersebut sebagai dampak dari faktor simpati tersebut. Contoh-contoh pada peristiwa yang terjadi dalam proses belajar mengajar 
penjas merupakan sebuah interaksi sosial yang berlangsung secara mendalam dan dengan jangka waktu yang relatif lama sebagai awal dimulainya suatu proses sosial.

Bentuk-bentuk interaksi sosial adalah kerjasama (cooperation), persaingan (competition), akomodasi (accomodation), dan bahkan juga dapat berbentuk pertentangan, atau pertikaian (conflict) (Soekanto 2012, hlm. 65). Bentuk-bentuk interaksi sosial itu terbagi ke dalam dua kategori yaitu proses-proses sosial yang assosiatif terdiri dari kerjasama (cooperation), akomodasi (accomodation), dan asimilasi (assimilation). Prosesproses sosial yang disosiatif terdiri dari persaingan (competition), kontravensi (contrvention), pertentangan (pertikaian atau conflict).

Permasalahan yang terjadi pada anak usia SD antara lain adalah permasalahan fisik, permaslahan psikis, stres (Maryanto, 2015). Permaslahan fisik yang terjadi pada anak usia SD yaitu pada usia 6-12 tahun atau kelas 1-6 adalah obsitas atau kegemukan. Penyebab kegemukan tersebut adalah akibat dari kurangnya berolahraga yang melibatkan fisik dan kelebihan makanan. Kurangnya kesadaran berolahraga disebabkan karena anak relatif kurang dalam penguasaan gerak dasar untuk melakukan aktifitas yang berhubungan dengan olahraga, hal tersebut menyebabkan anak enggan untuk melakukan kegiatan olahraga, berikutnya adalah permasalahan medis, anak pada usia SD relatif rentan terkena penyakit seperti demam, flu,virus, dan migrain (Maryanto, 2015). Berikutnya adalah kurangnya kebugaran jasmani anak, hal ini disebabkan oleh bawaan dari lahir, kecelakaan, dan akibat dari penyakit yang diderita, dengan keadaan seperti itu, anak enggan untuk melakukan kegiatan yang melibatkan fisik dikarenakan trauma. Kekurangan berat badan dan kekurangan gizi merupakan permaslahan lain dalam perkembangan fisik anak usia SD. Penyebab dari kurangnya berat badan bisa terjadi karena kekurangan asupan makanan yang bernilai gizi tinggi yang dibutuhkan anak pada masa pertumbuhan dan perkembangan, akibat dari kekurangan berat badan ini anak-anak cenderung tidak percaya diri dan menutup diri dari interaksi sosial.

Penjas sebagai salah satu mata pelajaran yang terdapat pada kurikulum tingkat SD memiliki peranan penting dalam mengantisipasi berbagai permasalahan yang dipaparkan di atas, baik permasalahan kogntif anak, apektif, dan psikomotor anak. Kerry Dyke's (2015, hlm.1) menyatakan mengenai landasan penjas sebagai mata pelajaran yang dapat mengembangkan aspek kognitif, apektif, dan psikomotor sebagai berikut: "Physical education is an integral part of the educative process which uses physical activity as a primary means to promote psychomotor, cognitive, and socio-affective growth in order to enhance the quality of life." Ungkapan tersebut menyatakan bahwa penjas (PE) adalah bagian integral dari pendidikan yang menggunakan aktivitas fisik sebagai dasar dalam mempromosikan domain psikomotor, kognitif, dan sosial-apektif dalam rangka meningkatkan kualitas hidup. Penjas merupakan media yang efektif dalam mengembangkan ke tiga ranah tersebut dalam proses belajar mengajar. Hal yang sama juga diungkapkan oleh Husdarta (2013, hlm.105) bahwa, "Kontribusi unik pendidikan jasmani terhadap perkembangan anak-anak adalah kontribusinya terhadap perkembangan aspek kemampuan dan keterampilan fisik siswa. Pendidikan jasmani juga bertanggung jawab terhadap perkembangan aspek kognitif dan apektif siswa. Untuk itu maka rumusan tujuan pendidikan jasmani harus meliputi kegiatan domain: kognitif, apektif, dan psikomotor."

Kemampuan gerak dasar ada tiga jenis yaitu lokomotor skills, non-lokomotor (stability skills) dan manipulatif skills. Kemampuan gerak merupakan keterampilan yang penting di dalam kehidupan sehari-hari maupun di dalam pelaksanaan KBM penjas itu sendiri. Artinya kemampuan gerak, pemahaman gerak dan sikap positif harus dimiliki oleh siswa dari mulai usia awal sekolah/Sekolah Dasar, karena gerak dasar merupakan kebutuhan yang sangat penting untuk melaksanakan kehidupan sehari-hari serta bekal untuk aktif dalam berbagai kegiatan olahraga siswa pada masa yang akan datang. Salah 
satu manfaat dari kegiatan olahraga adalah aspek sosial. Melalui media kegiatan olahraga dan aktifitas fisik, individu dapat melakukan interaksi dan bersosialisasi dengan anggota masyarakat yang lain. Pengalaman gerak dasar diperoleh siswa pada usia dini, yaitu saat mengikuti pembelajaran formal di sekolah dan ketika bermain di luar jam sekolah sebagai pondasi terhadap penguasaan gerak di usia dewasa kelak. Pengalaman pembelajaran penjas yang menyenangkan akan memberi dampak positif kepada siswa untuk kembali melaksanakan aktifitas jasmani di luar jam sekolah. Menurut Hoedaya (2009, hlm.23), “..., komponen apektif bisa diubah melalui pengalaman pembelajaran pendidikan jasmani yang menyenangkan." Sedangkan cara dalam membantu proses sosialisasi yang menjadi bagian aspek apektif anak-anak adalah melalui keanggotaan kelompok, seperti yang dikemukakan Kusmaedi, dkk (2004, hlm. 64-65 yaitu “..., dengan belajar bersaing dengan orang lain, belajar bekerja sama, belajar bermain dan olahraga.

Aktifitas bermain dan berolahraga bagi anak menjadi media pendidikan jasmani dalam usaha mencapai tujuan pembelajaran yang menyeluruh, oleh karena fungsi dan tujuan pendidikan jasmani adalah menumbuhkembangkan seluruh potensi yang ada pada siswa melalui aktifitas jasmani, termasuk juga dalam hal mengembangkan kemampuan sosial siswa. Altermann (1999, hlm. 374) menyatakan bahwa "Physical education is a natural practice ground for social interaction and an opportunity for observing social procces. These are seen within groups as well as between groups". Pendapat ini menegaskan bahwa pendidikan jasmani merupakan dasar latihan yang alamiah bagi interaksi sosial dan kesempatan untuk mengamati proses-proses sosial yang terjadi, baik dalam kelompok maupun antar kelompok.

Dalam meningkatkan kemampuan gerak dasar telah dikembangkan suatu program yang disebut program $F M S$, program ini telah di kembangkan diberbagai negara antara lain Amerika, Australia, Kanada, New Zeland, dll. Program ini merupakan program yang memberikan pondasi (Building Blocks) bagi penguasaan teknik gerak pada berbagai cabang olahraga. Program FMS ini memberikan kesempatan kepada siswa untuk mengembangkan kemampuan gerak dasar mereka melalui pembelajaran berbagai jenis aktifitas gerak. Perkembangan sosial yang terjadi pada diri siswa SD yang sesuai dengan harapan guru dan masyarakat tidak terjadi dengan sendirinya. Melalui pembelajaran penjas contohnya pada pembelajaran gerak dasar yang disajikan dengan berbagai pola pembelajaran salah satu contohnya adalah dengan program FMS diharapkan aspek sosial pada diri siswa dapat dioptimalkan. Program pembelajaran yang dimaksud adalah memberikan semua aktifitas yang terdapat dalam program $F M S$ yaitu aktifitas lokomotor, non-lokomotor dan manipulatif. Program FMS ini diharapkan dapat menjadi salah satu program pembelajaran yang dapat pengembangan kemampuan gerak dasar siswa serta mengembangkan proses sosial siswa, khusunya proses sosial asosiatif (kerjasama, akomodasi, asimilasi) dan mencoba mengurangi dampak negatif dari proses sosial disosiatif (persaingan, kontravensi, konflik).

\section{METODE PENELITIAN}

Dengan mengkaji permasalahan penelitian secara umum maka metode yang digunakan dalam penelitian ini adalah metode eksperimen. Nazir, (2011, hlm. 63) mengemukakan mengenai metode eksperimen sebagai berikut, "Eksperimen adalah observasi di bawah kondisi buatan (artificial condition) di mana kondisi tersebut dibuat dan diatur oleh si peneliti, dengan demikian, penelitian eksperimental adalah penelitian yang dilakukan dengan mengadakan manipulasi terhadap objek penelitian serta adanya kontrol."

Dalam konteks penelitian ini kelompok yang dimanipulasi adalah kelompok A dengan perlakuan program $F M S$, sedangkan kelompok yang menjadi kelompok kontrol 
adalah kelompok B tanpa perlakuan program FMS. Riduwan (2010, hlm. 50) mengemukakan bahwa, "Penelitian dengan pendekatan eksperimen adalah suatu penelitian yang berusaha mencari pengaruh variabel tertentu terhadap variabel yang lain dalam kondisi yang terkontrol secara ketat."

Dalam konteks penelitian ini variabel yang menjadi penyebab atau yang mempengaruhi (independent variable) adalah program FMS. Variabel yang dipengaruhi (dependent variable) atau yang mendapat akibat dari perlakuan variabel penyebab adalah pengembangan proses sosial yang terbagi ke dalam dua bentuk yaitu proses asosiatif dan proses disosiatif. Data penelitian hasil eksperimen diperoleh melalui tes akhir (post-test) menggunkan angket untuk kemudian dianalisis. Diadakannya tes akhir tentang pengembangan proses sosial (asosiatif dan disosiatif) adalah untuk mengatahui apakah terdapat pengaruh dari perlakuan (treatment) pada setiap kelompok sampel penelitian.

Desain yang digunakan dalam penelitian ini adalah Randomized Posttest-Only Control Group Designs. Variabel yang terdapat dalam penelitian ini terbagi menjadi dua variabel bebas (variabel yang mempengaruhi) dan variabel terikat (variabel yang dipengaruhi). Variabel bebas dalam penelitian ini adalah program Fundamental movement skills. Variabel bebas ini sekaligus merupakan bentuk perlakuan (treatment) yang diberikan kepada kelompok treatment, sedangkan kelompok lainnya disebut kelompok kontrol, yaitu kelompok yang tidak diberikan treatment. Sampel penelitian terbentuk menjadi dua kelompok (kelompok A dan kelompok B) dengan setiap kelompok memperoleh perlakuan (treatment) berbeda. Kelompok A diberikan perlakuan tentang program $F M S$, sedangkan kelompok B diberikan pembelajaran konvensional. Variabel terikat terdiri dari satu varibel yaitu pengembangan proses sosial dengan dua sub variabel yaitu; pengembangan proses sosial asosiatif yang terdiri dari aspek kerjasama, akomodasi, asimilasi. Kedua pengembangan proses sosial disosiatif yang terdiri dari aspek persaingan, dan konflik/kontravensi. Kedua sub-variabel ini menjadi indikator dari perubahan proses sosial sebagai dampak dari pemberian perlakuan (treatment) dari kedua varibel bebas.

\section{HASIL DAN PEMBAHASAN \\ Hasil}

Data hasil penelitian diperoleh dari hasil tes akhir (Post-test) dari setiap kelompok penelitian dengan menggunakan instrumen penelitian yang telah teruji validitas dan reliabilitasnya. Data dari hasil tes akhir ini kemudian dianalisis melalui prosedur statistik dengan menggunakan analisis dengan program software komputer Statistical Product and Service Solution (SPSS) Serie 19. Pada bagian ini penulis sajikan hasil analisis data secara sederhana berupa rangkuman. Untuk hasil analisis data secara lengkap, penulis uraikan pada bagian lampiran. Analisis diawali dengan deskripsi data hasil penelitian, hasil uji normalitas, hasil uji homogenitas, dan hasil uji hipotesis yang dilakukan untuk menjawab rumusan masalah penelitian yang diajukan. Berikut ini adalah rangkuman dari hasil analisis data angket pengembangan proses sosial (Asositif dan Disosiatif) siswa SD. Pengaruh Program FMS Terhadap Pengembangan Proses Sosial (Asosiatif) Siswa SD.

Tabel 1 Deskripsi data Pengaruh Program FMS Terhadap Pengembangan Proses Sosial (Asosiatif) Siswa SD

\begin{tabular}{lccc}
\hline \multicolumn{1}{c}{ Kelompok } & $\boldsymbol{N}$ & Mean & Std. Deviation \\
\hline FMS & 32 & 100.25 & 7.825 \\
KONVENSIONAL & 32 & 93.69 & 6.463 \\
\hline
\end{tabular}

Berdasarkan tabel 4.6 di atas, diketahui bahwa rata-rata skor pengembangan proses sosial (Asosiatif) pada kelompok program FMS adalah 100.25, sedangkan pada kelompok konvensional adalah 93.69. Sehingga dapat kita ambil kesimpulan bahwa rata-rata skor 
pengembangan proses sosial (Asosiatif) pada kelompok program FMS lebih besar dibandingkan dengan rata-rata skor proses sosial (Asosiatif) untuk kelompok konvensional, dapat diketahui bahwa program $F M S$ berpengaruh signifikan terhadap pengembangan proses sosial (Asosiatif) pada siswa SD.

Tabel 2 Hasil Uji Beda Pengembangan Proses Sosial (Asosiatif) Antara Program FMS dengan Konvensional

\begin{tabular}{|c|c|c|c|c|}
\hline \multicolumn{4}{|c|}{ t-test for Equality of Means } & \multirow{2}{*}{ Keterangar } \\
\hline $\mathbf{T}$ & Dk & $\begin{array}{c}\text { Sig. } \\
\text { (2-tailed) }\end{array}$ & Mean Difference & \\
\hline 3,658 & 62 & 0,001 & 6,56 & Signifikan \\
\hline
\end{tabular}

Hipotesis:

$\mathrm{H}_{0}$ : Tidak terdapat pengaruh program $F M S$ terhadap pengembangan proses sosial (asosiatif) siswa $\mathrm{SD} . \mathrm{H}_{1}$ : Terdapat pengaruh program $F M S$ terhadap pengembangan proses sosial (asosiatif) siswa SD

Kriteria keputusan:

Jika nilai probabilitas (p) Sig. $>0,05$ maka $\mathrm{H}_{1}$ diterima

Jika nilai probabilitas $(p)$ Sig. $<0,05$ maka $\mathrm{H}_{0}$ ditolak

Diketahui nilai thit 3,658 dengan probabilitas (p) Sig. 0,001 <0,05 maka $\mathrm{H}_{\mathrm{o}}$ ditolak dan $\mathrm{H}_{1}$ diterima, artinya bahwa "Terdapat pengaruh program $F M S$ terhadap pengembangan proses sosial (asosiatif) siswa SD". Apabila dilihat dari nilai rata-rata bahwa pengembangan proses sosial (Asosiatif) kelompok FMS memiliki rerata lebih tinggi dibandingkan kelompok konvensional dengan selisih rerata 6,56. Pengaruh Program FMS Terhadap Pengembangan Proses Sosial (disosiatif) Siswa SD

Tabel 3 Deskripsi Data Pengaruh Program FMS Terhadap Pengembangan Proses Sosial (disosiatif)

\begin{tabular}{lccc}
\multicolumn{4}{c}{ Siswa SD } \\
\hline Kelompok & N & Mean & Std. Deviation \\
\hline$F M S$ & 32 & 77.84 & 5.292 \\
KONVENSIONAL & 32 & 76.19 & 6.664 \\
\hline
\end{tabular}

Berdasarkan tabel 3 di atas, diketahui bahwa rata-rata skor pengembangan proses sosial (Disosiatif) pada kelas program FMS adalah 77.84, sedangkan pada kelas konvensional adalah 76.19. dengan selisih skor rata-rata adalah 1,65, Sehingga dapat kita ambil kesimpulan bahwa rata-rata skor pengembangan proses sosial (Disosiatif) pada kelas program FMS lebih besar dibandingkan dengan rata-rata skor proses sosial untuk kelas konvensional, dapat diketahui bahwa program FMS tidak berpengaruh signifikan terhadap pengembangan proses sosial (Disosiatif) siswa karena dari data hasil penelitian menyebutkan nilai signifikansinya adalah $0.275>0,05$

Tabel 4 Hasil Uji Beda Pengaruh Program FMS Terhadap Pengembangan Proses Sosial (disosiatif) Siswa SD

\begin{tabular}{ccccc}
\hline \multicolumn{4}{c}{ t-test for Equality of Means } & \multirow{2}{*}{ Keterangan } \\
\hline T & Dk & Sig. (2-tailed) & Mean Difference & \\
\hline 1,101 & 62 & 0,275 & 1,65 & Tidak Signifikan \\
\hline
\end{tabular}

Hipotesis:

$\mathrm{H}_{0}$ : Tidak terdapat pengaruh program $F M S$ terhadap pengembangan proses sosial (disosiatif) Siswa SD. $\mathrm{H}_{1}$ : terdapat pengaruh Program FMS Terhadap Pengembangan Proses Sosial (disosiatif) Siswa SD 
Kriteria keputusan:

Jika nilai probabilitas ( $p$ ) Sig. $>0,05$ maka $\mathrm{H}_{1}$ diterima

Jika nilai probabilitas ( $p$ ) Sig. $<0,05$ maka $\mathrm{H}_{0}$ ditolak

Diketahui nilai thit 1,010 dengan probabilitas (p) Sig. 0,275 $>0,05$ maka $\mathrm{H}_{\mathrm{o}}$ diterima dan $\mathrm{H}_{1}$ artinya bahwa "Tidak terdapat pengaruh program $F M S$ terhadap pengembangan proses sosial (disosiatif) Siswa SD".

\section{Pembahasan}

Menurut Department of Education WA (2013, hlm.1) menyatakan bahwa, "Being proficient in fundamental movement skills enables children to participate confidently in play, dance, games, sport, outdoor education and recreational activities at home, at school and in the community. This Resource emphasises the importance of integration and valuing the social, emotional, cultural, linguistic, creative, spiritual and cognitive needs of children as well as their movement skills."

Dari penjelasan diatas dapat difahami bahwa anak-anak yang memiliki gerakan dasar (FMS) yang mahir, akan memungkinkan berpartisipasi dengan kepercayaan diri yang tinggi dalam berbagai aktfitas yang melibatkan fisik, hal tersebut akan berbanding lurus dengan tingkat interaksi sosial karena mereka tidak segan untuk bergabung dengan suatu komunitas sosial dengan bekal kemampuan keterampilan dasar yang tinggi. Keterampilan dasar ini menjadi media bagi anak-anak untuk dapat bergabung dengan komunitas sosial dan berinteraksi dengan dengan teman yang lainnya.

Seorang anak yang mempunyai kemampuan motorik yang baik akan mempunyai rasa percaya diri yang besar. Lingkungan teman-temannya pun akan menerima anak yang memiliki kemampuan motorik atau gerak yang lebih baik, sedangkan anak yang tak memiliki kemampuan gerak tertentu akan kurang diterima teman-temannya. Penerimaan teman-teman dan lingkungannya akan menyebabkan anak mempunyai rasa percaya diri yang baik. Contohnya, seorang anak yang sedari kecil sudah belajar berlari atau menggambar yang lebih baik daripada teman-temannya yang lain, ia akan diterima dengan baik oleh teman-teman sebayanya. Ia akan mempunyai banyak teman dan kegiatannya pun akan semakin banyak karena ia akan diajak mengikuti berbagai kegiatan lainnya. Oleh sebab itu, sebaiknya saat anak-anak kecil mereka dapat mulai mempelajari berbagai jenis kegiatan fisik/motorik secara bebas sesuai dengan kemampuan mereka sendiri dan tanpa dibanding-banding dengan anak lainnya. Hal itu akan membuat anak mau melakukan berbagai kegiatan dengan senang hati tanpa rasa takut dan malu.

Pengaruh Program FMS Terhadap Pengembangan Proses Sosial (disosiatif) siswa SD. Pembelajaran yang tradisional masih bersifat kaku, terikat pada peraturan dan teknik dasar dengan tuntutan penguasaan prestasi/Sport Oriented (PLPG Penjaskes 2014). Dalam pembelajaran konvensional siswa diarahkan untuk menguasai teknik dasar suatu kecabangan olahraga, dan biasanya pembelajarannya cenderung pada metode kompetitif. Hal tersebut mamungkinkan siswa terjebak dalam penguasaan salah satu atau dua cabang olahraga, yang seharusnya siswa khusunya siswa Sekolah Dasar harus di berikan pengalaman gerak yang banyak (Multilateral). Berdasarkan penelitian yang telah dilakukan bahwa pembelajaran konvensional yang bersifat kompetitif berpengaruh kepada proses sosial (Disosiatif). Proses Sosial Disosiatif/Oppositional/Oposisi dapat diartikan sebagai cara berjuang melawan seseorang atau sekelompok manusia untuk mencapai tujuan tertentu. (Soekanto, 2013).Proses Sosial (Disosiatif) diantaranya adalah persaingan/Competition, Kontravensi/Contravention, dan pertentangan/pertikaian atau Conflict.

Pendapat lain mengenai anak yang kurang mahir dalam melakukan FMS akan mendapat beberapa hal negatif seperti yang dikemukakan oleh Cote dkk. (2008) sebagai 
berikut, "Children who lack the Fundamental Movement Skills are likely to experience frustration and difficulty learning more advanced skills, thereby reducing their enjoyment of sport and physical activity. Children tell us that not having the skills to play is one major reason they drop out of sport and physical activity. Research shows that 'negative self-perception of motor ability is a major barrier to participation', and "without the development of Fundamental Movement Skills many children withdraw from physical activity and sport, and turn to more inactive and/or unhealthy choices during their leisure time."

Pendapat di atas menjelaskan bahwa anak-anak yang memiliki kekurangan dalam melakakukan Keterampilan Gerakan Fundamental (FMS) memilki kecenderungan mengalami frustrasi dan kesulitan belajar keterampilan yang lebih lanjut, sehingga mengurangi mereka dalam menikmati aktiftas olahraga dan aktivitas fisik yang lainnya. Survey yang dilakukan oleh cote dkk. (2008) menyebutkan bahwa anak-anak yang tidak memiliki keterampilan dasar untuk bermain menjadi salah satu alasan utama mereka meninggalkan aktifitas olahraga dan aktivitas fisik lainnya. Penelitian ini menunjukkan bahwa persepsi diri negatif mengenai kemampuan motorik adalah penghalang utama untuk dapat berpartisipasi dalam aktifitas olahraga dan aktifitas fisik lainnya, Tanpa memiliki pengembangan Keterampilan Gerakan Fundamental (FMS) yang banyak, anak akan menarik diri dari aktivitas fisik dan olahraga, dan beralih memilih aktiftas yang pasif dan/atau tidak sehat selama waktu luang mereka.

\section{KESIMPULAN}

Berdasarkan hasil pengolahan dan analisis data diperoleh jawaban atas pertanyaanpertanyaan penelitian yang telah diajukan pada rumusan masalah yang tertuang sebelumnya. Jawaban atas pertanyaan penelitian ini sekaligus sebagai kesimpulan. Adapun kesimpulan dalam penelitian ini adalah sebagai berikut: Program Fundamental Movement Skills dapat memberikan pengaruh yang signifikan terhadap pengembangan proses sosial (Asosiatif) yang terdiri dari aspek kerjasama (cooperation), akomodasi (accomodation), dan asimilasi (assimilation). Program Fundamental Movement Skills tidak dapat memberikan pengaruh terhadap pengembangan proses sosial (disosiatif) yang terdiri dari aspek persaingan (competitif), Kontravensi (contravention), dan pertentangan/conflict. Secara umum, hasil dari penelitian ini dapat menggambarkan bahwa program $F M S$ dapat memberikan pengaruh terhadap aspek psikomotor berupa keterampilan berbagai bentuk gerak (lokomotor, non-lokomotor, dan manipulatif). Program FMS ini juga memberikan manfaat berupa pemahaman kepada siswa mengenai berbagai bentuk gerak dasar serta berbagai jenis gerak yang terdapat di dalammnya, dengan keterampilan dan pemahaman yang baik mengenai berbagai gerak dasar siswa dapat mempergunakan keterampilan dan pemahamannya sebagai media untuk berinteraksi dan bersosialisasi dengan lingkungan sekitar, aktif dalam aktifitas fisik, dan memberikan nilai lebih pada tingkat kepercayaan diri dalam kehidupan sosial khususnya pada aspek proses sosial.

\section{REKOMENDASI}

Penulis mengharapkan bahwa penelitian ini menjadi salah satu bahan pengembangan pada aspek kerjasama, akomodasi, dan asimilasi yang diakibatkan oleh program fundamental movement skills dan mampu mengembangkan wawasan keilmuan pada bidang psikomotor

\section{UCAPAN TERIMA KASIH}

Penulis mengucapkan terima kasih yang tidak terhingga atas bantuan dari pihak luar yang tidak dapat disebutkan yang sudah membantu dalam proses penelitian ini. 


\section{DAFTAR PUSTAKA}

Akbari, Hakimeh. (2009). The Effect Of Traditional Games In Fundamental Motor Skills Development In 7-9 Year Old Boys. Yeman University. Iran. Departement of excercise and physical sciences.

Alfermann, Dorothee. (1999). Teacher Student Interaction and Interaction Pattern in Student Group. Phychology For Physical Educators, Fepsac. Human Kinetic.

Amarin, Tatang M. (2014). Taksonomi Bloom Versi Baru. [Online] Tersedia: http://tatangmanguny.wordpress.com/2014/12/25/taksonomi-bloom-versi-baru-2/.

Diakses 25 Desember 2014.

Anitah, Sri. dan Supriyati, Yetti (2007). Strategi Pembelajaran di SD. Jakarta : Universitas Terbuka

Apruebo, Roxel A. (2005). Sport Psycology. Manila; UST Publishing House.

Bloom, B. S. ed. et al. (1956). Taxonomy of Educational Objectives: Handbook 1, Cognitive Domain. New York: David McKay. [Online]. Tersedia di: https://id.wikipedia.org/wiki/Taksonomi_Bloom. [Diakses tanggal 25 Juni 2015].

BSNP. (2006). Model KTSP dan Model Silabus Mata Pelajaran SD/MI. Jakarta: BP. Cipta Jaya

Bucher, Charles. A. (1972). Foundation of Physical Education. Sixth Edition. CV. Mosby Company.

Budiman, Didin. (2009). Model Pengembangan Proses Sosial Siswa SD Melalui Metode dan Pendekatan Mengajar Pendidikan Jasmani. Bandung. Tesis, Universitas Pendidikan Indonesia.

Chief Curriculum Development Officer (Physical Education) (2007) An Introductory Guide To Fundamental Movement. Bureau. Hong Kong. Physical Education Section Curriculum Development Institute.

Cholik M. Toho \& Lutan, Rusli. (1996/1997) Pendidikan Jasmani dan Kesehatan, Jakarta: Depdiknas Dirjen Dikti Bagian Proyek Pengembangan Pendidikan Guru Sekolah Dasar.

Delas, Suncica. Dkk. (2007). The Influence Of Motor Factors On Performing Fundamental Movement Skills - The Differences Between Boys And Girls. Croatia. Facta Universitatis.

Depdikbud. (1995). Kamus Besar Bahasa Indonesia. Jakarta : Balai Pustaka.

Departement Of Education (2013) Fundamental Movement Skills, Learning, teaching and Assesment. Preparing children for an active and healty lifestyle. Western Australia.

Departement Of Education (2000) Get Skilled, Get Aktiv. Resource to Support The Teaching of Fundamental Movement Skills. New Shouth Wales. 
Departement Of Education (2001) Get Skilled, Get Aktiv. Resource to Support the Teaching of Fundamental Movement Skills. New Shouth Wales.

Firdaus, Tama. (2014). Definisi Metode Menurut Para Ahli. [Online].

Tersedia di: http://www.eurekapendidikan.com/2014/10/definisi-metode-menurutpara-ahli.html. [Diakses 19 Juni 2015]

Freankle, Wallen, Hyun. (2012). How To Design and Evaluate Research in Education. United States. Mc Grawhill Company.

Gallahue, David L. (1998). Understanding Motor Development In Children: Jhon Wiley \& Sons.

Hands, P. Beth \& Martin, Marie (2003). Implementing a Fundamental Movement Skills program in early childhood setting; the children perspective. Universitas of Notre Dame. Australia

Haryanto, (2009). Pendidikan Karakter Menurut Ki Hadjar Dewantara. Kurikulum dan Teknologi Pendidikan FIP UNY. [Online]. Tersedia di: http://staff.uny.ac.id/sites/default/files/131656343. [Diakses 17 September 2015]

Hoedaya, Danu. (2009). Pendekatan Psikologis dalam Olahraga Usia Dini Buku Pedoman Pelatihan Usia Dini. Jakarta: Kementrian Negara Pemuda dan Olahraga Republik Indonesia Bidang Peningkatan Prestasi dan Iptek Olahraga Pengembangan SDM Keolahragaan.

Hoedaya, Danu. (2009). Empati Dalam Kehidupan Bermasyarakat Tinjauan Potensi Pendidikan Jasmani Dalam Pendidikan Watak. Makalah. Bandung: FPOK UPI.

Husdarta dan Yudha. (2000).Belajar Dan Pembelajaran. Bandung: Depdiknas.

Husdarta. J. S, (2014) Psikologi Olahraga. Bandung: Alfabeta.

Huky, Willa. (1982). Pengantar Sosiologi. Surabaya: Usaha Nasional.

Kusmaedi, Nurlan., Husdarta J. S. (2012). Pertumbuhan \& Perkembangan Peserta Didik (Olahraga dan Kesehatan). Bandung: Alfabeta.

Lutan, Rusli., \& Cholik, T. (1997). Strategi Pembelajaran Pendidikan Jasmani dan Kesehatan. Buku Materi Pokok, Depdikbud-Dikdasmen, BP2MG Penjaskes Setara D-II, Universitas Terbuka, Jakarta.

Malina, R. \& Bouchard, C. (1991), Growth, Maturation, and Physical Activty, Human Kinetics Book: Illinois.

Ma, mun, Amung. \& Saputra M.Y. (2000). Perkembangan Gerak dan Belajar Gerak. Jakarta: Depdiknas.

Margono. A. Dkk. (2014). Bahan Ajar PLPG Pendidikan Jasmani Olahraga dan Kesehatan. FKIP Universitas Siliwangi: Tasikmalaya 
Martin, Marie. (2003). Fundamental Movement Skills, Teacher's Perpectives. University Of Notre Dame. Australia

Maryanto, (2012) Permasalahan Anak Sekolah Dasar. Online tersedia di http://li2kmaryanto.blogspot.co.id/2012/06/permasalahan-anak-sekolah-dasar.html. Diakses tanggal 04 Desember 2015

Nazir, Moh. (2011). Metode Penelitian. Bogor : Ghalia Indonesia.

Octaria, Dina. (2012). Teori Asosiasi (Stimulus-Respon). [Online]. Tersedia di: https://dinaoctaria.wordpress.com/2012/10/15/teori-asosiasi-stimulus-respon-dariedward-lee-thorndike/. Diakses 20 Juni 2015.

Oxendine, Joseph B. (1968). Phsychology of Motor Learning. New York: Appleton. Century-Croft, Division Or Meredith Corporation.

Payne, V.G., dan Isaacs, L.D. (1995). Human motor development: A lifespan approach. thitrd edition. Mountain View, CA.: Mayfield Publishing Company.

Program Pendidikan Jasmani Kesehatan dan Rekreasi. (2008) Physical education, helath, and Recreation journal. Universitas Sebelas Maret.

Riduwan. (2010). Belajar Mudah Penelitian - untuk Guru - Karyawan dan Peneliti Pemula. Bandung: C.V. Alfabeta.

Schmidt, Richard A. (2000). Motor Learning and Performance. Los Angles: Human Kinetics.

Singer, R.N; Dick, W.(1980). Teaching Physical Education: A System Approach. Bostoon; Houghton Miflin Company.

Soekanto, Soerjono. (2012). Sosiologi Suatu Pengantar. Jakarta: Rajawali Pers.

Sport New Zealand. (2012). Introduction Fundamental Movement Skills. [On line] tersedia di: www.sportnz.org.nz. Diakses tanggal 25 Mei 2015.

Susanto, Astrid S. (2006). Pengantar Sosiologi dan Perubahan Sosial. Bandung: Bina Cipta.

Suharsimi, Arikunto. (2003). Prosedur Penelitian Suatu Pendekatan Praktek. Jakarta: Rineka Cipta

Suharsimi, Arikunto. (2013). Prosedur Penelitian. Suatu Pendekatan Praktik. Rineka Cipta: Jakarta

Suherman, Adang. (2009). Revitasli Pengajaran Dalam Pendidikan Jasmani. Perpustakaan nasioanal RI.

Sugiyono. (2013). Statistika Untuk Penelitian. Bandung: CV. Alfabeta. 
Sugiyanto dan Sujarwo. (1991). Materi Pokok Perkembangan dan Belajar Gerak. Buku I Modul 1-6. Jakarta: Depdikbud Proyek Penataran Guru SD Setara D-II Bagian Proyek Penataran Guru.

Sujiono, Yuliani \& Sujiono, Bambang. (2010). Bermain Kreatif Berbasis Kecerdasan jamak. Jakarta: Indeks.

Thomas, Jerry R., Thomas, Khaterine T., Lee, Amelia M. (1988) Physical Education For Children: Concepts Into Practice. Champaign, Illinois: Human Kinetics Books.

Yudiana, Yunyun (2009). Implementasi Model Pendekatan Taktis Dalam Pembelajaran Permainan Bola Voli Di Sekolah Menengah Pertama. Disertasi. FPOK-UPI. Bandung. 